\title{
ANALISIS TINGKAT LIKUIDITAS DAN PROFITABILITAS UNTUK MENILAI KINERJA KOPERASI KREDIT SWASTIASTU PADA TAHUN 2014-2016
}

\author{
Putu Kuni Diviana \\ Jurusan Akuntansi Program Diploma III, \\ Universitas Pendidikan Ganesha, Singaraja \\ e-mail : divianikuni4@gmail.com
}

\begin{abstract}
Abstrak
Penelitian ini bertujuan menganalisis tingkat likuiditas dan profitabilitas untuk menilai kinerja Koperasi Kredit Swastiastu pada tahun 2014-2016. Subjek dalam penelitian ini adalah Koperasi Kredit Swastiastu. Metode pengumpulan data yang digunakan dalam penelitian ini adalah metode dokumentasi. Data dianalisis menggunakan teknik analisis deskritif kuantitatif.

Dari hasil penelitian, dalam tiga tahun menunjukkan rasio likuiditas Koperasi Kredit Swastiastu kurang efesien atau belum menunjukkan kemampuan dalam keberlangsungan koperasi untuk melunasi hutang jangka pendek. Namun, rasio profitabilitas Net Profit Margins dan Return on Equity sudah efisien, namun pada Return on Assets pada Koperasi Kredit Swastiastu masih kurang efesien.
\end{abstract}

Kata Kunci : Analisis tingkat Likuiditas dan Profitabilitas

Abstract

This study aimed to analyze the level of liquidity and profitability to assess the performance of Koperasi Kredit Swastiastu in 2014-2016. Subjects in this study is the Koperasi Kredit Swastiastu. Data collection methods used in this research is the method of documentation. Data were analyzed using quantitative descriptive analysis techniques.

From the research, within three years shows the ratio of liquidity Koperasi Kredit Swastiastu less efficiently or has not shown the ability in the sustainability of cooperatives to repay short-term debt. However, the profitability ratios Net Profit Margins and Return on Equity has been efficient, but the Return on Assets in Koperasi Kredit Swastiastu still less efficiently.

Keywords: Analysis of the level of liquidity and profitability.

\section{Pendahuluan}

Koperasi adalah suatu badan usaha yang berbadan hukum dan berlandaskan atas azas kekeluargaan dan azas demokrasi ekonomi. Koperasi mempunyai tujuan seperti yang tercantum dalam Undang Undang Nomor 25 pasal 3 yaitu memajukan kesejahteraan anggota pada khususnya dan masyarakat pada umumnya, serta ikut membangun tatanan perekonomian nasional dalam rangka mewujudkan masyarakat yang maju, adil dan makmur berlandaskan Pancasila dan Undang Undang Dasar 1945. Alasan menggunakan koperasi simpan pinjam dalam penelitian ini karena koperasi simpan pinjam merupakan koperasi yang sumber utama dananya berasal dari anggota yang kemudian disalurkan kepada anggotanya. Karena itu koperasi simpan pinjam memerlukan likuiditas yang tinggi untuk meningkatkan profitabilitasnya

Salah satu koperasi simpan pinjam yang Bali tepatnya di kecamatan Buleleng adalah Koperasi Kredit (Kopdit) Swastiastu. Kopdit Swastiastu dipilih dalam penelitian ini karena dilihat dari jumlah anggota dari tahun 2014 sampai tahun 2016 terus mengalami peningkatan yaitu 5.824 orang di tahun 2014, 6.355 orang di tahun 2015 dan 7.113 orang di tahun 2016 . Selain itu jumlah nasabah dari tahun ke tahun mengalami peningkatan dilihat dari hutang tabungan yang dimiliki Kopdit Swastiastu dari tahun 2014 sampai tahun 2016 yaitu sebesar Rp. 23.223.160.642 di tahun 2014, sebesar Rp. 27.067.144.032 di tahun 2015 dan sebesar Rp. 32.203.337.575 di tahun 2016. Ini membuktikan bahwa Kopdit Swastiastu sudah mendapat kepercayaan dari masyarakat.

Untuk mengetahui kondisi koperasi, dapat diukur dengan menilai kinerja koperasi tersebut. Kinerja diartikan sebagai hasil dari usaha seseorang yang dicapai dengan adanya 
kemampuan dan perbuatan dalam situasi tertentu. Kinerja suatu koperasi dapat dilihat dari data laporan keuangan yang dimiliki oleh koperasi. Pengukuran kinerja dilakukan pada Kopdit Swastiastu menggunakan analisis likuiditas dan profitabilitas karena peneliti ingin mengetahui apakah koperasi ini mampu memenuhi hutang jangka pendeknya dan apakah koperasi ini mampu menghasilkan SHU sesuai dengan standar yang ada.

Analisis rasio keuangan merupakan metode analisis yang sering dipakai karena merupakan metode yang paling cepat untuk mengetahui kinerja keuangan koperasi. Dengan diketahui kinerjanya, koperasi akan dapat melakukan perkiraan keputusan apa yang diambil guna mencapai tujuannya. Hal tersebut karena suatu badan usaha koperasi akan dapat berusaha agar menjadi badan usaha yang modern. Analisis likuiditas yakni menunjukkan kemampuan suatu koperasi untuk memenuhi kewajiban-kewajiban keuangan yang harus segera dipenuhi atau kemampuan koperasi untuk memenuhi kewajiban keuangan tepat pada saat ditagih. Koperasi yang mampu memenuhi atau membayar kewajiban keuangan tepat pada waktunya disebut likuid, yaitu apabila aktiva lancar lebih besar daripada hutang lancar. Sedangkan koperasi yang tidak mampu memenuhi atau membayar kewajiban keuangan tepat pada waktunya disebut illikuid. Analisis profitabilitas koperasi diukur dari kesuksesan koperasi dan kemampuan menggunakan aktivanya secara produktif, dengan demikian profitabilitas suatu koperasi dapat diketahui dengan memperbandingkan antara Sisa Hasil Usaha yang diperoleh dalam suatu periode dengan jumlah aktiva atau jumlah modal koperasi tersebut. Berdasakan hal di atas maka peneliti berminat melaksanakan penelitian dengan judul Analisis Tingkat Likuiditas Dan Profitabilitas Untuk Menilai Kinerja Koperasi Kredit Swastiastu Pada Tahun 2014-2016.

\section{Metode Penelitian}

Pada rancangan penelitian hal yang pertama kali dilakukan adalah menentukan lokasi penelitian dimana penulis melakukan penelitian pada Kopdit Swastiastu yang beralamat Jalan Laksamana Barat No. 9, Baktiseraga, Kec Buleleng, Kab. Buleleng. Setelah lokasi penelitian telah ditentukan barulah peneliti melihat fenomena atau hal-hal seperti apa yang terjadi di Kopdit Swastiastu. Kemudian dari fenomena tersebut dapat dibuat rumusan masalahya. Kajian teori dibuat setelah rumusan masalah, ini dimaksudkan untuk mengetahui materi-materi apa saja yang dapat digunakan untuk penelitian ini. Dari kajian teori ini, peneliti dapat menentukan data-data apa saja yang diperlukan untuk meneliti. Data yang digunakan dalam penelitian ini berupa data kuantitatif yang berasal dari laporan keuangan koperasi yang didalamnya terdapat neraca dan laporan laba/rugi koperasi. Data yang telah diperoleh kemudian diolah dan dianalisis menggunakan analisis rasio likuiditas dan profitabilitas. Dari pengolahan data tersebut penulis mendapatkan hasil penelitian, dari hasil penelitian ini nantinya dapat disimpulkan apakah kinerja Kopdit Swastiastu dari tahun 2014-2016 sudah baik atau belum baik.

\section{Hasil dan Pembahasan}

Cash Ratio untuk tahun buku yang berakhir 31 Desember 2014 adalah sebesar $7,89 \%$ ini berarti Kopdit Swastiastu mampu melunasi 7,89\% dari besar hutang lancarnya. Rasio ini menunjukkan hutang lancar sebesar Rp. 37.547.735.286 dengan kas sebesar Rp. 741.656.746 dan bank sebesar Rp. 2.221.369.342. Dengan kata lain, cash ratio pada Kopdit Swastiastu kurang efisien karena hutang lancar pada tahun 2014 masih cukup tinggi dibanding total kas dan bank dengan jumlah Rp. 2.963.026.088. Pada tahun berikutnya yaitu tahun 2015 cash ratio sebesar 18,28\% artinya mengalami peningkatan dibandingkan tahun sebelumnya. Kopdit Swastiastu mampu melunasi 18,28\% dari besar hutang lancarnya. Rasio ini menunjukan hutang lancar sebesar Rp. 43.496.462.162 dengan jumlah kas dan bank sebesar Rp. 7.951.999.407. Ini berarti cash ratio pada Kopdit Swastiastu tahun 2015 cukup efisien karena jumlah hutang lancar terjadi peningkatan sebesar Rp. 5.948.726.876 diimbangi dengan jumlah kas dan bank pada koperasi tersebut yang juga mengalami peningkatan sebesar Rp. 4.988.973.319. Pada tahun berikutnya yaitu tahun 2016 cash ratio 
sebesar $9,03 \%$ artinya mengalami penurunan dibandingkan tahun sebelumnya. Penurunan ini terjadi karena jumlah kas dan bank yang menurun, namun hutang lancar pada koperasi tersebut mengalami peningkatan. Kopdit Swastiastu mampu melunasi 9,03\% dari besar hutang lancarnya. Rasio ini menunjukan hutang lancar sebesar Rp. 50.838.044.500 dengan jumlah kas dan bank sebesar Rp. 4.595.197.678, ini berarti cash ratio pada tahun 2016 mengalami penurunan dari tahun sebelumnya. Cash ratio pada Kopdit Swastiastu untuk tahun 2016 masih kurang efisien karena hutang lancar yang dimiliki masih cukup tinggi karena mengalami kenaikan sebesar Rp. 7.341.582.338 sedangkan pada total kas dan bank hanya mengalami kenaikan sebesar Rp. 3.356.801.729.

Berdasarkan pembahasan di atas, cash ratio pada Kopdit Swastiastu untuk tahun 2014-2016 dilihat dari hubungan antara perbandingan kas dan bank dengan hutang lancar yang dimiliki Kopdit Swastiastu dikatakan masih kurang baik karena nilai total kas dan bank masih terlalu sedikit dibandingkan dengan nilai total hutang lancarnya.

Current Ratio pada tahun 2014 adalah 119,33\% yang berarti Kopdit Swastiastu berada dalam kondisi likuid dikarenakan hutang lancar sebesar Rp. 37.547.735.286 yang harus dikembalikan dijamin dengan aktiva lancar yang dimiliki sebesar Rp. 44.807.425.831. Berdasarkan standar, current ratio sebesar 119,33\% dikatakan kurang efisien karena hutang lancar pada koperasi yang tinggi diimbangi dengan aktiva lancar yang tinggi. Namun pada tahun berikutnya yaitu tahun 2015 current ratio mengalami kenaikan menjadi 122,13\%. Namun menurut standar, current ratio pada tahun 2015 dinyatakan kurang efisien padahal hutang lancar maupun aktiva lancar mengalami kenaikan yang cukup tinggi yaitu sebesar Rp. 43.496.462.162 untuk hutang lancar dan sebesar Rp. 53.126.077.038. Ini berarti posisi hutang lancar sebagai pembagi masih cukup tinggi dibanding aktiva lancarnya. Pada tahun 2016 current ratio kembali mengalami peningkatan dari tahun sebelumnya yaitu dengan persentase $122,36 \%$. Ini dikarenakan aktiva lancar mengalami kenaikan menjadi Rp. 62.207.225.698 dan hutang lancar juga mengalami kenaikan menjadi Rp. 50.838.044.500. Menurut standar, current ratio pada tahun 2016 kurang efisien karena standar pada tahun 2016 masih kurang dari 125\%.

Berdasarkan pembahasan di atas, current ratio pada Kopdit Swastiastu untuk tahun 2014-2016 dilihat dari perbandingan antara jumlah aktiva lancar dengan hutang lancar yang dimiliki Kopdit Swastiastu dikatakan masih aman karena Kopdit Swastiastu mampu memenuhi kebutuhan hutang lancarnya pada saat jatuh tempo.

Net Profit Margin merupakan perbandingan antara SHU dengan Pendapatan Operasional Kopdit Swastiastu periode 2014-2016. Pada tahun 2014 net profit margin adalah sebesar $10,13 \%$. Jadi setiap Rp 1,00 Pendapatan Operasional akan menghasilkan SHU 10,13\% yaitu sebesar Rp 0,1013. Berdasarkan standar diatas net profit margin Kopdit Swastiastu dinilai sudah efisien karena koperasi tersebut mampu mencapai net profit margin lebih dari 10\%. Pada Tahun 2015 net profit margin mengalami peningkatan dibandingkan tahun sebelumnya menjadi 10,23\%. Jadi setiap Rp 1,00 Pendapatan Operasional akan menghasilkan SHU 10,23\% yaitu sebesar Rp 0,1023. Berdasarkan standar diatas, net profit margin dinilai efisien karena telah terjadi kenaikan pada sisa hasil usaha sebesar Rp. 124.113.904 akibat pendapatan operasionalnya mengalami kenaikan sebesar Rp. 1.169.834.724. Pada tahun berikutnya Tahun 2016 net profit margin mengalami penurunan dari tahun sebelumnya menjadi 7,82\%. Jadi setiap Rp 1,00 Pendapatan Operasional akan menghasilkan SHU 7,82\% yaitu sebesar Rp 0.0782. Berdasarkan standar diatas, net profit margin dinilai cukup efisien karena sisa hasil usaha mengalami penurunan dibanding tahun sebelumnya sebesar Rp.124.113.904 namun pada pendapatan operasionalnya mengalami peningkatan sebesar Rp. 145.631.001 dari tahun sebelumnya. Ini berarti beban-beban yang dikeluarkan Kopdit Swastiastu lebih besar dari tahun sebelumnya sehingga SHU yang dihasilkan mengalami penurunan Dari tabel diatas, menunjukkan bahwa net profit margin pada Kopdit Swastiastu terus mengalami fluktuasi dari tahun ke tahun.

Berdasarkan pembahasan di atas, net profit margin pada Kopdit Swastiastu untuk tahun 2014-2016 dapat disimpulkan bahwa pendapatan yang dimiliki oleh Kopdit Swastiastu sudah mampu menghasilkan SHU yang terus mengalami kenaikan, walaupun untuk tahun 
2016 SHU koperasi tersebut mengalami penurunan karena adanya peningkatan biaya-biaya untuk kegiatan operasinya.

Return on Asset merupakan perbandingan antara SHU dengan Total Aktiva yang dimiliki Kopdit Swastiastu pada tahun 2014-2016. Pada Tahun 2014 Return on Asset sebesar $0,88 \%$ yang artinya setiap Rp 1,00 Total Aktiva akan menghasilkan SHU yaitu sebesar Rp 0,0088 berarti koperasi kurang efisien, karena sisa hasil usaha yang masih terbilang kecil yaitu sebesar Rp. 451.996 .755 sedangkan total aktivanya yang cukup tinggi yaitu Rp. 51.060.441.039. Pada tahun berikutnya yaitu tahun 2015 return on assets pada Kopdit Swastiastu sebesar 0,97\% mengalami peningkatan dibandingkan tahun sebelumnya yang artinya setiap Rp 1,00 Total Aktiva akan menghasilkan SHU yaitu sebesar Rp 0,0097 walaupun terjadi peningkatan namun return on assets pada tahun ini masih kurang efisien karena peningkatan pada sisa hasil usaha yang tidak terlalu tinggi yaitu Rp. 124.133.904 diikuti dengan kenaikan total aktiva yang cukup tinggi mencapai Rp. 8.061.654.357. Pada tahun berikutnya yaitu tahun 2016 return on assets sebesar $0,65 \%$ mengalami penurunan yang cukup drastis dibandingkan tahun sebelumnya yang artinya setiap Rp 1,00 Total Aktiva akan menghasilkan SHU yaitu sebesar Rp 0,0065 hal ini berarti koperasi kurang efisien, ini terjadi karena kenaikan pada sisa hasil usaha tahun 2016 tidak sebanding dengan kenaikan total aktiva, dimana sisa hasil usaha Kopdit Swastiastu pada tahun 2016 adalah sebesar Rp. 451.869.482 ini berarti terjadi penurunan nilai SHU sebesar Rp. 124.241.177 sedangkan total aktiva pada tahun 2016 sebesar Rp. 68.713.740.150 mengalami kenaikan yang cukup tinggi yaitu sebesar Rp. 9.591.644.754.

Berdasarkan pembahasan di atas, return on assets pada Kopdit Swastiastu untuk tahun 2014-2016 masih belum efisien karena koperasi tersebut belum mampu menghasilkan SHU yang tinggi walapun aktiva yang dimilikinya terbilang cukup tinggi.

Return on Equity (ROE) merupakan perbandingan antara SHU dengan Kekayaan Bersih yang dimiliki oleh Kopdit Swastiastu tahun 2014 - 2016. Pada tahun 2014 Return on Equity (ROE) sebesar 3,46\%\%. Jadi setiap Rp 1,00 Kekayaan Bersih akan menghasilkan SHU 3,46\% yaitu sebesar Rp 0,0346 Berdasarkan standar Return on Equity (ROE) Kopdit Swastiastu pada tahun 2014 kurang efisien, ini karena dengan modal sebesar Rp. 13.060.708.998, Kopdit Swastiastu hanya menghasilkan SHU sebesar Rp. 451.996.755 Ini berarti jumlah modal yang dimiliki koperasi hanya mampu untuk memberikan SHU sebanyak $3.46 \%$. Pada tahun 2015 Return on Equity (ROE) sebesar 3,82\%, mengalami peningkatan dibandingkan tahun sebelumnya. Jadi setiap Rp 1,00 Kekayaan Bersih akan menghasilkan SHU) 3,82\% yaitu sebesar Rp 0,0382. Berdasarkan standar Return on Equity (ROE) Kopdit Swastiastu pada tahun 2015 kurang efisien karena modal pada tahun 2014 yang mengalami kenaikan hanya sedikit yaitu sebesar $\mathrm{Rp}$. 1.988.813.577 sehingga menjadi Rp. 15.049.522.575 hanya mampu menghasilkan SHU sebesar Rp. 576.110.659 dimana SHU ini mengalami kenaikan hanya sedikit yaitu sebesar Rp. 124.113.904. Ini berarti jumlah modal yang dimiliki koperasi hanya mampu untuk memberikan SHU sebanyak $3.82 \%$. Pada tahun berikutnya yaitu tahun 2016 Return on Equity (ROE) pada Kopdit Swastiastu mengalami penurunan yang cukup drastis menjadi 2,59\%. Jadi setiap Rp 1,00 Kekayaan Bersih akan menghasilkan Sisa Hasil Usaha (SHU) 2,59\% yaitu sebesar Rp 0,0259. Menurut standar, Return on Equity (ROE) Kopdit Swastiastu pada tahun 2016 masih tetap kurang efisien karena modal yang mengalami kenaikan sebesar Rp.2.374.303.593 sehingga menjadi Rp. 17.423.826.168 hanya mampu menghasilkan SHU sebesar Rp. 451.869.482 dimana SHU pada tahun 2016 mengalami penurunan sebesar Rp. 124.241.177. Ini berarti jumlah modal yang dimiliki koperasi sudah mampu untuk memberikan SHU sebanyak 2,59\%.

Berdasarkan pembahasan di atas, return on equity pada Kopdit Swastiastu untuk tahun 2014-2016 dilihat dari sumber daya yang dimiliki untuk memberikan SHU atas ekuitas dikatakan sudah efisien karena modal yang dimiliki oleh Kopdit Swastiastu sudah mampu menghasilkan SHU yang cukup besar. 


\section{Simpulan dan Saran}

Berdasarkan hasil penelitian pada Kopdit Swastiastu menggunakan analisis rasio likuiditas dan profitabilitas maka dapat disimpulkan bahwa rasio likuiditas yang digunakan untuk mengetahui kemampuan perusahaan dalam memenuhi kewajiban jangka pendeknya pada saat jatuh tempo. Alat yang digunakan untuk mengukur rasio ini adalah dengan membandingkan antara aktiva lancar dengan hutang lancar. Pada Kopdit Swastiastu dalam kemampuannya memenuhi kewajiban jangka pendeknya dari tahun 2014 sampai 2016 dilihat dari kemampuan kas dan banknya kurang baik karena nilai total kas dan bank masih terlalu sedikit dibandingkan dengan nilai total hutang lancarnya. Namun kemampuan koperasi dalam memenuhi hutang jangka pendeknya dapat optimal karena adanya peningkatan aktiva lancar dimana total semua sub-sub dalam aktiva lancar kemudian dibandingkan dengan hutang lancar yang dimiliki Kopdit Swastiastu menunjukkan bahwa koperasi ini mampu untuk memenuhi kewajiban jangka pendeknya. Selain itu hasil penelitian juga menunjukkan bahwa Kopdit Swastiastu masih aman dalam memenuhi hutang lancarnya pada saat jatuh tempo.

Sedangkan pada rasio profitabilitas dimana rasio ini menunjukkan kemampuan koperasi untuk memperoleh sisa hasil usaha dalam periode tertentu. Profitabilitas suatu koperasi dapat diketahui dengan memperbandingkan antara SHU yang diperoleh dalam suatu periode dengan jumlah aktiva atau jumlah modal koperasi tersebut. Pada Kopdit Swastiastu dalam kemampuannya menghasilkan SHU maka dapat disimpulkan bahwa aktiva, pendapatan dan modal yang dimiliki oleh Kopdit Swastiastu sudah mampu menghasilkan SHU yang terus mengalami kenaikan dari tahun 2014-2015, namun pada tahun 2016 SHU yang dihasilkan Kopdit Swastiastu mengalami penurunan dikarenakan adanya peningkatan beban-beban yang dikeluarkan Kopdit Swastiastu pada tahun 2016. Hasil ini menunjukkan bahwa Kopdit Swastiastu mampu untuk menghasilkan SHU yang lebih baik nantinya ditahun-tahun yang akan datang. Karenanya walaupun ada peningkatan beban-beban, Kopdit Swastiastu memiliki kemampuan untuk menggunakan seluruh dana dan seluruh sumber daya untuk menghasilkan keuntungan sehingga Kopdit Swastiastu memiliki kemanpuan menghasilkan laba yang baik.

\section{Daftar Pustaka}

Amstrong, Mischael, 1999. Manajemen Sumber Daya Manusia. Terjemahan

Anwar Prabu Mangkunegara, (2002), Manajemen Sumber Daya Manusia, PT. Remaja

Case, Karl E. dan Ray C. Fair, 2001. Prinsip-Prinsip Ekonomi Makro. Edisi Kelima,Cetakan Cetakan Pertama, PT Raja Grafindo Persada, Jakarta.

Dessler, Gary. 2000. Human Resource Management 8th Edition. New Jersey: Prentice-Hall, Haryanto. PT. Elex Media Komputindo. Jakarta.

http//id.shvoong.com (diakses tanggal 26 Februari 2017)

http://deptan.go.id (diakses tanggal 26 Februari 2017)

Luthans, Fred, 2005. Perilaku Organisasi, Edisi Sepuluh, Diterjemahkan oleh : Vivin Andhika Mulyadi. 2001. Sistem Akuntansi, Yogyakarta : STIE YKPN.

Mulyono, Teguh Pudjo. (1995). Analisa Laporan Keuangan Untuk Perbankan, Edisi revisi III. Jakarta: Penerbit Djambatan.

Munawir, 2001. Akuntansi Keuangan dan Manajamen, Edisi Pertama, BPFE, Yogyakarta.

Nurlaila, 2010. Manajemen Sumber Daya Manusia I. Ternate: Penerbit LepKhair Pendek), Edisi keempat, BPFE, Yogyakarta.

Rivai, Veithzal dan Ahmad Fawzi Mohd Basri, 2005. Performance Appraisal.

Rudianto.2006."Akuntansi Koperasi", Jakarta : Grafindo

Suad Husnan, 2003, Manajemen Keuangan Teori dan Penerapan (keputusan Jangka 
VOL.6, NO. 2, OKTOBER, 2017

p-ISSN : 2337-537X

Sugiyono. 2012. Metode Penelitian Kuantitatif Kualitatif dan R\&D. Bandung: Alfabeta.

Undang-Undang Dasar Republik Indonesia No. 25 Tahun 1992 tentang Perkoperasian.

Undang-Undang Dasar Tahun 1945 Pasal 3 Ayat 1 tentang pengertian koperasi. Yogyakarta.

Yuwono; Shekar Purwanti; Th.Arie Prabawati; dan Winong Rosari. Penerbit Andi, 